\title{
Male Feminists Promote Gender Equality in Islamic Moderation Perspective
}

\author{
Maghfur Ahmad1 ${ }^{*}$, Siti Mumun Muniroh², Umi Mahmudah ${ }^{3}$ \\ 1 Institut Agama Islam Negeri Pekalongan, Indonesia; maghfur@iainpekalongan.ac.id \\ 2 Institut Agama Islam Negeri Pekalongan, Indonesia; siti.mumun.muniroh@iainpekalongan.ac.id \\ 3 Institut Agama Islam Negeri Pekalongan, Indonesia; umi.mahmudah@iainpekalongan.ac.id \\ * Correspondence: maghfur@iainpekalongan.ac.id
}

Received: 2021-02-05; Accepted: 2021-07-17; Published: 2021-08-21

\begin{abstract}
This study aimed to analyze the relationship between the role of men in supporting the feminist movement and moderate Islamic teachings among college students in Indonesia. This study used a quantitative approach by distributing questionnaires to 625 respondents who were randomly selected. The independent variable used, namely religious moderation, was measured using four indicators: a sense of nationalism $\left(X_{1}\right)$, tolerance $\left(X_{2}\right)$, anti-violence $\left(X_{3}\right)$, and accommodative attitudes towards local culture $\left(X_{4}\right)$. This study examined multiple linear regression analysis to test whether the four problems in Islamic moderation were related to student attitudes towards male involvement in feminism. The results suggested that these four independent variables have a positive and significant effect on student attitudes towards the active role of men in supporting the gender equality movement. Furthermore, an accommodative attitude towards the local culture and a sense of nationalism were known to have the greatest and smallest effects, namely 0.28 and 0.15 respectively. These results indicate that moderate Muslims tend to have a greater acceptance of male feminists. Then, the results also indicated that Muslim students who practised moderate Islamic teachings had realized the importance of male involvement in feminism.
\end{abstract}

Keywords: Anti-violence; feminism; Islamic moderation; male feminists.

Abstrak: Penelitian ini bertujuan untuk menganalisis hubungan antara peran laki-laki dalam mendukung gerakan feminis dengan ajaran Islam moderat di kalangan mahasiswa di Indonesia. Penelitian ini menggunakan pendekatan kuantitatif dengan menyebarkan kuesioner kepada 625 responden yang dipilih secara acak. Variabel independen yang digunakan, yaitu moderasi beragama, diukur menggunakan empat indikator: rasa nasionalisme $\left(X_{1}\right)$, toleransi $\left(X_{2}\right)$, anti kekerasan $\left(X_{3}\right)$, dan sikap akomodatif terhadap budaya local $\left(X_{4}\right)$. Untuk menguji apakah keempat masalah moderasi Islam berhubungan dengan sikap siswa terhadap keteribatan laki-laki dalam feminisme, penelitian menguji analisis regresi linier berganda. Hasil penelitian ini menunjukkan bahwa keempat variable independen ini berpengaruh positif dan signifikan terhadap sikap siswa terkait peran aktif laki-laki dalam mendukung gerakan kesetaraan gender. Selanjutnya, sikap akomodatif terhadap budaya lokal dan rasa nasionalisme diketahui memiliki pengaruh terbesar dan terkecil, yaitu masing-masing 0,28 dan 0,15. Hasil ini mengindikasikan bahwa muslim yang moderat cenderung memiliki sikap penerimaan yang lebih besar terhadap feminis laki-laki. Kemudian, hasil penelitian juga mengindikasikan bahwa mahasiswa Muslim yang mempraktekkan ajaran Islam moderat telah menyadari pentingnya keterlibatan laki-laki dalam feminisme.

Kata Kunci: Anti-kekerasan; feminisme; male feminists; moderasi Islam. 


\section{Introduction}

The feminist movement has grown rapidly in all countries around the world, including Indonesia. It is a social movement to fight the oppression of women, such as discrimination, marginalization, and violence. One of its main goals is to provide awareness of gender equality in all aspects of life, not only for women but also for men (Jackson, Fleury, \& Lewandowski, 1996; Precopio \& Ramsey, 2017). Traditional patriarchal culture negatively affects both men and women, which usually triggers genderbased violence (Craig, 2014; Precopio \& Ramsey, 2017). Therefore, women and men are responsible for supporting this movement (Fadlan, 2012; Prasad et al., 2021; Subašić et al., 2018; Sweetman, 2013; Wiley, Srinivasan, Finke, Firnhaber, \& Shilinsky, 2013). Moreover, emphasizing only on the part of women will not produce effective results in creating equality as expected (Precopio \& Ramsey, 2017; Wandi, 2015).

Men need to be part of the feminist movement. Men need to be actively involved in fighting for gender equality because it can encourage other men to take an active role in supporting feminism (Kleynjan, 2019; Precopio \& Ramsey, 2017). However, the presence of men in the feminist movement is a complex issue (Craig, 2014; De Wolf, 2015; Hasyim, 2014; Kleynjan, 2019; Prasad et al., 2021; Precopio \& Ramsey, 2017; Silver, Chadwick, \& van Anders, 2019). Pro-feminism men are required to be willing and able to support women's equal rights, but at the same time, they are also aware of the possibility of losing their privileges as men (Kleynjan, 2019). There is also a fear among men to be considered effeminate when they are called feminist activists. There is a concern among them to endangering men's position in a patriarchal society (Conlin \& Heesacker, 2018; Precopio \& Ramsey, 2017). Men's credibility as feminists is often under suspicion and underestimation (Crowe, 2011). They even face threats of being labelled effeminate and subject to slander, humiliation, and physical assault (Wiley et al., 2013). These fears make men less interested in joining social movements for gender equality (Hooks, 2000).

The involvement of men in promoting gender equality in Indonesia has also been investigated (Arivia, 2006; Asrini \& Dhamayanti, 2018; Hasyim, 2014, 2017; Larasati \& Astuti, 2019; Prasetya \& Suprapto, 2020; Rahman, 2017; Sumiyatiningsih, 2014; Wandi, 2015). The New Men's Alliance (Aliansi Laki-Laki Baru-ALB) became the pro-feminist men's movement in Indonesia. This movement is an effort and commitment made by a group of men who have awareness and concern to end patriarchal gender relations (Larasati \& Astuti, 2019). The men in this alliance joined after they experienced a realization of the oppression experienced by the women around them (Hasyim, 2017). By having a good feminist awareness, men as the dominant group in gender-based oppression can be part of the struggle to eradicate gender-based injustice (Hasyim, 2014, 2017). Therefore, it is important to pay attention to men's awareness of gender equality from a feminist perspective (Wandi, 2015).

The existence of male feminists in Indonesia has started to get support from various parties. There are also many community and religious leaders who actively and openly support gender equality. The role of religious leaders is important because they become role models for younger Muslims to participate in the gender equality movement's success actively. The younger generation of Muslims needs to be encouraged to be aware of gender equality so that they are more interested in participating in this movement. One of the efforts to promote gender equality among Indonesian youth is by promoting religious moderation. This promotion can be carried out through various activities such as social campaigns, seminars, workshops, symposia, focus group discussions, training, personal intervention, or introducing new approaches, models, and methods (Manshur \& Husni, 2020). Thus, it is important to carry out an in-depth analysis of the views of Muslim students on activities that reflect the role of men in gender equality. The relationship between their religious attitudes and the presence of male feminists needs to be investigated.

This study analyzes the relationship between the religiousness of Muslim students in college and the activities of male feminists. Do students who have a more open religious attitude have a better chance of accepting and following male feminist activities to support feminism? This study provides a clear picture based on empirical data regarding student perceptions based on their religious attitudes towards the existence of male feminists. This study also provides concrete evidence based on the assumptions that Muslim students have an open view of all-male activities in the gender equality 
movement. Thus, this research provides many benefits for various parties to promote gender equality in Indonesia, especially with the involvement of male feminists.

\section{Research Method}

This research uses quantitative methods to analyze the attitudes of Muslims towards men who support the feminist movement. However, this study only focuses on Muslim students who practice moderate Islamic teachings. Then, this study also focuses on the perceptions and attitudes of moderate Muslim students towards all forms of support by men in promoting gender equality. Thus, this research includes both passive and active support from men for gender equality. For this purpose, this study used survey data by distributing questionnaires to $625 \mathrm{Muslim}$ students. The survey was conducted by randomly selecting respondents at one of the State Islamic universities in Central Java, Indonesia. This campus is indicated to have implemented moderate Islamic teachings following the instructions of the Indonesian Ministry of Religion. Thus, although this survey was conducted randomly, it has used a purposive sampling approach by only targeting students affiliated with moderate Islam. Thus, the sample data obtained are relevant to the main objective of this study and have implications for valid analysis results and reduces estimation bias. The sampling was conducted on 7-25 December 2019 using the online survey method.

This study uses multiple regression methods. There are four indicators of religious moderation used, namely national commitment $\left(X_{1}\right)$, tolerance $\left(X_{2}\right)$, non-violence $\left(X_{3}\right)$, and accommodative attitudes towards local culture $\left(X_{4}\right)$. The independent variable used in this study is religious moderation of Muslim students, where the indicators adopt religious moderation from the Indonesian Ministry of Religion (The Ministry of Religion of the Republic of Indonesia, 2019). Approval of Pancasila as the state ideology, attitudes toward ideological challenges that are contradictory to Pancasila, nationalism, and acceptance of the 1945 Constitution's national values are among the items used to measure the national nationality variable $\left(X_{1}\right)$. The attitude to offer space and not interfere with others' rights, open attitude, open-mindedness, voluntary, and kindness in tolerating differences are among the items used to measure the tolerance variable $\left(X_{2}\right)$. Items to measure the non-violence variable $\left(X_{3}\right)$ refers to antiradicalism or violence, including attitudes towards terrorism and inter-religious violence. Items to measure the variable accommodative attitudes towards local culture $\left(X_{4}\right)$ include accepting religious practices that accommodate local culture and traditions, such as tahlilan, yasinan, et cetera.

Meanwhile, the dependent variable $(Y)$ used is students' attitude towards male activists who play an active role in the feminist movement. All items on the dependent variable refer to male feminist characteristics introduced by Arivia (2006) and Asrini \& Dhamayanti (2018). Male feminists characteristics include having a sense of caring for their surroundings such as family and society; having a sense of tolerance and pluralism; providing freedom, democratic, and participatory; willing to do household chores; anti-polygamy; promote an aura of freedom; use language that is empowering and not derogatory; always cares about the domestic workload; and respect women's roles and activities (Arivia, 2006; Asrini \& Dhamayanti, 2018). Each statement item on all indicators on both variables is measured using a Likert scale from 1 to 5 . Score 1 represents the respondent's answer who strongly disagrees. Conversely, a score of 5 indicates the response is very agreeable.

The product-moment correlation approach and Cronbach Alpha are utilized in the validity and reliability tests of the research instrument, respectively. The validity test indicates that all instrument items can be deemed valid, where the product-moment correlation analysis's significance value ( $\mathrm{p}$ value) is less than 0.05 . Further, the reliability test gives a Cronbach alpha value of 0.81 , leading to a reliable research instrument.

\section{Islamic Moderation and Feminism in Indonesia}

In general, the definition of moderation refers to the word wasatiyyah in Arabic refers to several patterns of meaning such as justice or balance ( $\left.a l-^{\prime} a d l\right)$, reward or excellence ( $\left.a l-f a d l\right)$, better ( $a l-$ khairiyyah), median (al-bainiyyah) (Al-Sallabi, 1999; Islam \& Khatun, 2015). Then, moderation means a balanced choice, between two good things and two bad things or a middle position (Al-Sallabi, 1999; 
Islam \& Khatun, 2015). Moderation is a balance that balances two opposite ends, where neither end stands alone (al-Qaradawi, 2011). Moderation means the elected, the best, fairness, not extreme in worldly or the afterlife (Hanapi, 2014). Wasatiyyah refers to individual characteristics and collective behavior that are considered moderate, balanced, not overreacting, or extreme (Yaakub \& Othman, 2016). In the Koran, the term al-wasatiyyah (religious moderation) is found in some of Allah's advice, namely al-wusta (al-Baqarah, 2:238), awsat (al Ma'idah, 5:89), awsatuhum (al-Qalam, 68:28), and fawasatna (al-'Adiyat, 100:5). This term also refers to moderate people (ummatan wasatan) (Hanapi, 2014). Thus, the term moderation has the same meaning as the term wasatiyyah.

In Indonesia, religious moderation has been regulated by the Ministry of Religion of the Republic of Indonesia. Islam and all moderate religions in Indonesia also encourage all adherents not to be extreme and excessive in addressing diversity. One of the most important aspects of religious moderation is tolerance (The Ministry of Religion of the Republic of Indonesia, 2019). Moderate religious teachings produce a type of religion that is moderate and tolerant. Therefore, it becomes a powerful tool in dealing with differences in Indonesia such as beliefs, differences in race, gender, differences in sexual orientation, ethnicity, and culture (Kawangung, 2019). The Ministry of Religion provides an indicator to identify how strong religious moderation is adhered to by Indonesian citizens. There are four variables of religious moderation, namely (1) national commitment, (2) tolerance, (3) non-violence, and (4) accommodating local culture. Hence, these indicators can also be used to detect the vulnerability of a citizen's religious moderation. This vulnerability needs to be recognized to identify and take appropriate steps to strengthen religious moderation (The Ministry of Religion of the Republic of Indonesia, 2019).

Moderate Islam requires Muslims to be open-minded and not isolate themselves and live exclusively. Thus, they are also required to be able to integrate, adapt, and keep up with the times, including the gender equality movement. The general public still considers Islamic teachings to hinder gender equality (Prado, 2012; Raftari \& Bahrami, 2011). The presumption that Islam and feminism are opposites could hinder the gender equality movement (Alexander \& Welzel, 2011; Glas \& Alexander, 2020; Glas, Spierings, \& Scheepers, 2018; Lussier \& Fish, 2016). However, there are also Muslims who support gender equality but still adhere to Islamic values (Glas \& Alexander, 2020).

Muslim feminists are those who believe that the existing patriarchal system is not convenient with the principles of the Koran on gender equality and justice (Harisuddin, 2015). Thus, Muslim feminists base their arguments by interpreting the Koran and religious texts in rejecting the patriarchal system (Badran, 2013). They believe that Islam is not against feminists even Islamic teachings uphold equality between men and women. Thus, religion can be used to promote critical discourse on gender equality (Rinaldo, 2014). Strengthening the interpretation of emancipatory religions is an effective way to improve gender equality in the Arab region, where most of the population is Muslim (Glas \& Alexander, 2020).

The development of Islamic feminism in Indonesia cannot be separated from Islamic mass organizations in increasing the role of women, where they facilitate women to contribute to society and the State (Arivia \& Subono, 2017). Two Islamic organizations greatly influenced the struggle for women's emancipation initiated by RA Kartini, namely Muhamadiyah and Nahdlatul Ulama (Arivia \& Subono, 2017). Both Muhamadiyah and Nahdlatul Ulama have succeeded in effectively including the voices of Muslim women who are actively working to promote and integrate women's rights into all areas of public life (Parvanova, 2012). It should be noted that these two Islamic organizations represent moderate Islam that maintains balance in Indonesia (Abdurrohman, 2018; Darajat, 2017; Hilmy, 2012; Salik, 2019). Both are known to introduce and promote peaceful Islamic teachings persistently. There have been many studies analyzing their role in improving the welfare of women and fighting for gender equality (Ahmad, 2020). These two organizations provide a significant role for women in fighting for their rights through their respective women's wing movements, namely Aysyiyah and Muslimat NU, respectively (Arivia \& Subono, 2017; Parvanova, 2012).

To defend their ideas on gender equality, Indonesian Muslim women activists have successfully implemented re-reading the Koran and reinterpreting Islamic sources (Parvanova, 2012). Islamic 
feminism in Indonesia is encouraged by using a well-accepted approach, which combines principles in Islam and the ideas of the feminist movement, gender equality, and human rights (Parvanova, 2012). They all indicate moderate Islamic teachings that promote openness and adaptability. These teachings are not rigid in interpreting verses of the Koran and hadiths (The Ministry of Religion of the Republic of Indonesia, 2019). Conversely, fundamentalist, which is rigid in interpreting Allah's commands and prohibitions, tends to hinder feminists from promoting gender equality (Widani, 2017). These teachings have the potential to limit women's ability to express their opinions or ideas. Then, women in Islamic Fundamentalist groups tend to feel oppressed (Widani, 2017).

Therefore, moderate Muslims need to take an active role in pushing the gender equality movement in Indonesia, Muslim women and men. This is because the involvement of Muslim men, especially leaders of Islamic mass organizations, is believed to be able to accelerate and facilitate women's struggles in fighting gender-based violence (Muhammad, 2019). Indonesian female Muslim feminist figures who support the active role of men in gender equality are Shinta Nuriyah Wahid, Khofifah Indar Parawansa, and Siti Musdah Mulia. Meanwhile, male religious and community leaders who actively and openly support and strive for gender equality include Abdurrahman Wahid, Masdar Farid Masudi, Nasaruddin Umar, Fazlur Rahman, and Husein Muhammad (Harisuddin, 2015; Rahman, 2017). These figures practice moderate Islamic teachings in their daily lives. So, openness and support from various parties are needed, so that gender equality runs well. Even, encouragement is needed for women to become public leaders (Parawansa, 2015).

\section{Male Feminists Activities in Indonesian Context}

Pro-feminist men in the last few decades have become an interesting phenomenon to be observed. Especially after the United Nations launched a campaign to involve men for gender equality and justice (Larasati \& Astuti, 2019). Definitions and characteristics that describe the identity of men as activists of the feminist movement have been put forward by researchers (Arivia, 2006; Baily, 2015; Kleynjan, 2019; Pease, 2015; Precopio \& Ramsey, 2017; Subašić et al., 2018; Van der Gaag, 2014). Even though they are actually pro feminists, not a few men who supported this movement expressed their dislike of being labeled as male feminists (Craig, 2014; Kleynjan, 2019; Van der Gaag, 2014). Men who have been involved in the feminist movement are described as supporters of movements that defend women, such as feminist activists, women's rights activists, and gender rights activists. Although they are rarely identified as male feminists (Van der Gaag, 2014).

Male feminists are expected to help end the oppression of women considering that patriarchal men are believed to be the main perpetrators of this oppression (Burrell \& Flood, 2019; Klocke, 2013). Many researchers have advocated for men's involvement in the feminist movement (Baily, 2012, 2015; Ben Salah \& Wernli, 2016; Conlin \& Heesacker, 2018; De Wolf, 2015; Van der Gaag, 2014). Feminism that involves both men and women is more attractive, thus providing greater opportunities for the movement to develop quickly and be accepted openly (Baily, 2012, 2015). Not a few men are interested in supporting feminism and fighting violence perpetrated against women and girls (Flood, 2011; Flood, Russell, O’Leary, \& Brown, 2017; Pease, 2015). Boys and men are able and interested to take action to support the feminist movement (Bojin, 2013). The majority of men are willing to fight against the violence and abuse women and girls face (Flood, 2011). Moreover, the feminist movement has also attracted the attention of male celebrities around the world, who have spoken openly about their interest in gender equality (Feasey, 2017). In this case, it makes senses that every man has a woman in their life whom they love and respect. Consciously or not, their lives are affected by these women. Then, men also benefit when women and girls around them have safe and fair lives (Flood et al., 2017). Thus, men need to change their attitudes and behaviors that might contribute to violence against women.

When discussing men's roles as feminists, most of them make explicit distinctions between the two types of "doing feminism", namely "active" and "passive" (Kleynjan, 2019). Active feminism represents the demands on men to actually create and develop social change. It involves public political activism, and professional teaching in the areas of feminist theory or gender studies. Passive feminism, on the other hand, is practised away from public scrutiny and works in the background by listening, 
studying, and informally educating men in their social circles by challenging sexism and hatred of women (Kleynjan, 2019).

In order to identify as feminists, men must first have an understanding and awareness of what it means to be feminists (Hasyim, 2017; Kleynjan, 2019; Klocke, 2013; Precopio \& Ramsey, 2017). Doing feminism also requires empathy (Kleynjan, 2019). Pro-feminist men need to overcome attitudes and behaviors that lead to violence against women (Flood, 2011). Male feminists are required to be able to show attitudes, ways of thinking, and actions based on the basic ideologies of feminism, such as antiviolence, anti-discrimination, anti-domination, and anti-oppression in their daily lives (Baily, 2012). Pro-feminism men are required to create and develop social change, such as public political activism and professional teaching in the field of feminist theory or gender studies (Pease, 2015). Furthermore, being a male feminist means exercising men's privileges to support women and the feminist movement (Kleynjan, 2019).

Male feminists have the following characteristics, namely (1) having a sense of caring for their surroundings such as family and society; (2) having a sense of tolerance and pluralism; (3) providing freedom, democratic, and participatory; (4) willing to do household chores; (5) anti-polygamy (Arivia, 2006). Feminist men promote an aura of freedom, use empowering and not derogatory language, always cares about the domestic workload, and respect women's roles and activities (Asrini \& Dhamayanti, 2018). Male feminist representations can be seen from two perspectives, namely their mindset and behavior in society (Prasetya \& Suprapto, 2020). The male feminist mindset is rejecting violence against women, being willing to do domestic work, and opposing the negative image of women in the media and culture. Meanwhile, male feminist behavior is respecting women, doing domestic work, and maintaining a positive image of women in society (Prasetya \& Suprapto, 2020).

\section{Male Feminists Activities and Islamic Moderation among Muslim Students}

This section provides the results of the analysis and discussion of this study. The general description of respondents can be described as follows. The results of the analysis of the data description indicate that the average age of the respondents is 20 years, where the youngest and oldest respondents are 16 and 33 years old, respectively. A total of 259 respondents are male students or the equivalent of $41.40 \%$. Meanwhile, the female respondents are 366 respondents or $58.60 \%$. Then, $40.00 \%$ of the respondents are found to be in their third year of study on campus.

The model summary in the regression analysis indicates a positive (although not very strong) correlation between all the independent and dependent variables used in this study. This is based on the correlation coefficient $(R)$ which gives a figure of 0.48 . Thus, Islamic moderation correlates positively with men's perceptions of supporting the gender equality movement. The result suggests Muslims who practice moderate Islamic teachings tend to have better perceptions and behaviors and are more open to all male activities in supporting the feminist movement. Table 1 shows the regression estimation results, which describes the regression coefficient and the significance of the analysis results.

From table 1, there are four independent variables or predictors used $(X)$, where $X_{1}$ shows the respondent's commitment or sense of nationalism to the unity and integrity of Indonesia, $X_{2}$ indicates the respondent's tolerance attitude, $X_{3}$ indicates non-violence, and $X_{4}$ indicates the respondent's accommodative attitude towards local culture in Indonesia. When the dependent variable $(Y)$ represents male feminist, which is the activities carried out by men in supporting and promoting gender equality, either passively or actively.

Table 1 shows the regression analysis results, representing the magnitude of each independent variable's influence on the dependent variable $(Y)$. The estimation results in table 2 show the small standard error of the estimated values for all independent variables, where the average standard error value is 0.05 . It was important to note that standard error values represented the average distance from observed values that fall from the regression line. The smaller standard error value was better because the observation was closer to the fitted line. 
Table 1. Estimates Regression

\begin{tabular}{|c|c|c|c|c|c|c|}
\hline & \multirow[t]{2}{*}{ Model } & \multicolumn{2}{|c|}{$\begin{array}{c}\text { Unstandardized } \\
\text { Coefficients }\end{array}$} & \multirow{2}{*}{$\begin{array}{c}\text { Standardized } \\
\text { Coefficients }\end{array}$} & \multirow[t]{2}{*}{$t$} & \multirow[t]{2}{*}{ Sig. } \\
\hline & & $B$ & Std. Error & & & \\
\hline \multirow[t]{5}{*}{1} & (Constant) & 8.69 & 1.03 & & 8.44 & 0.00 \\
\hline & $X_{1}$ & 0.15 & 0.05 & 0.12 & 2.98 & 0.03 \\
\hline & $X_{2}$ & 0.21 & 0.04 & 0.20 & 4.87 & 0.00 \\
\hline & $X_{3}$ & 0.20 & 0.05 & 0.15 & 3.80 & 0.00 \\
\hline & $X_{4}$ & 0.28 & 0.07 & 0.18 & 4.28 & 0.00 \\
\hline
\end{tabular}

a. Dependent Variable: Male feminist

Based on table 1, the regression estimation results show that all indicators of religious moderation have a positive effect on men's involvement in the feminist movement. This can be seen from the regression coefficients for all independent variables, which all give positive values. A sense of nationalism $\left(X_{1}\right)$ produces a regression coefficient of 0.15 , while tolerance $\left(X_{2}\right)$ produces a regression coefficient of 0.21 . Then, from table 2, the variable anti-violence attitude (X3) and accommodative attitude towards local culture (X4) provide regression coefficients of 0.20 and 0.28 , respectively. Thus, the results suggest that the most positive indicator of men's involvement in feminism is an open and accommodating attitude toward local culture, indicated by the largest regression coefficient.

Furthermore, these effects are also known to be statistically significant, where all significance values or $p$-values are greater than 0.05 . In conclusion, the influence of the four independent variables is positive and statistically significant on male participation in feminism. In other words, there is a positive relationship between the religious attitudes of students who practice moderate Islamic teachings and their attitudes towards the role of male feminists. Thus, when the level of moderation in students' religion increases, they tend to be more receptive to the existence of male feminists.

Turning to the regression coefficient of each independent variable, from table 2 it is known that the variable sense of nationalism $\left(X_{1}\right)$ provides a regression coefficient of 0.15 . This result means that when the national commitment variable $\left(X_{1}\right)$ increases by one unit, it is expected that there will be an increase of 0.15 units in student attitudes towards the existence of male feminists. So, based on table 2, it is known that an increase in the tolerance attitude variable $\left(X_{2}\right)$ by 1 point causes an increase in the acceptance of male activists in feminism by 0.21 points. Every one-unit increase in the anti-violence variable $(\mathrm{X} 3)$ is predicted to increase student attitudes towards the involvement of male feminists by 0.20 points. Then, every one-unit increase in the variable of student accommodation attitudes towards culture and local wisdom values is projected to cause an increase in their attitudes towards the existence of male feminists by 0.28 points.

These results also suggest that moderate Islam tends to accept the existence of male feminists because its adherents practice open and not rigid Islamic teachings. They practice justice and balance and do not be excessive and extreme in their daily lives (Hanapi, 2014; Yaakub \& Othman, 2016). Hence, these results are also in line with the Ministry of Religion's presentation, which states the character of religious moderation requires openness, acceptance, and cooperation. Thus, Muslim students who have good religious moderation as well as have an open attitude are willing to accept and cooperate with other parties. They can treat others with dignity, accept differences, and live together in peace and harmony. Individuals who have good religious moderation tend to be balanced. Those with a balanced attitude imply that they are assertive but not stubborn (The Ministry of Religion of the Republic of Indonesia, 2019).

Therefore, it is not surprising that students who practice religious moderation are more receptive to the concept of gender equality and other women's movements because they believe that Islamic teachings also place women in a good and high place so that they cannot be harassed. Feminism 
enhances the position of women in all aspects of life and eliminates all practices that belittle and harass women (Altwaiji, 2011). As a result, those with a moderate understanding of religion have better attitudes and perceptions towards feminist activists, both men, and women. Furthermore, it is natural that followers of moderate Islam are welcome to all those who promote the gender equality movement. It is also understandable when they allow men to be involved in feminism because they see the benefits provided by men. Simply put, people with a moderate Islamic view, namely those who are openminded and not rigid, tend to be able to accept the rapidly moving times, including male activists in the women's movement. They are willing to accept the feminist movement because they believe it does not diminish their belief in fundamental Islamic teachings. They are more receptive to male feminist presence because of their openness. This is also under the teachings of moderate Islam which ignore all differences to uphold goodness.

Furthermore, most respondents agreed or strongly agreed with all forms of male activity in supporting the gender equality movement, which is $89.28 \%$. The few respondents who object to the existence of male feminists indicate that most Muslim students have realized the importance of the role of men in the gender equality movement. By implication, they also acknowledge that the women's movement may develop more quickly if men are actively involved. These findings are also in line with previous studies that reported the importance of the role of men in feminism. Their role is more able to attract other parties to support this movement (Kleynjan, 2019; Muhammad, 2019; Parawansa, 2015; Pease, 2015; Van der Gaag, 2014). Men can be allies for women in the success of the feminist agenda (Hasyim, 2017). This role has been proven by the existence of big figures such as Masdar Farid Masudi, Nasaruddin Umar, Fazlur Rahman, and Husein Muhammad (Rahman, 2017). The most prominent male figure in the development of the gender equality movement in Indonesia is Abdurrahman Wahid, the former president of the Republic of Indonesia (Rahman, 2017). This male figure's role inspires women activists to voice women's equality at all levels of life (Muhammad, 2019) and inspires the birth of a generation of feminist men. The new generation of male feminists are Faqihuddin Abdul Kodir, Abdul Muqsid Ghozali, Marzuki Wahid, Kurdi Fadlol, Naqho'i, Nuruzzaman, , Isfah Abidal Aziz, M. Al-Furqon, and Nur Hasyim. These feminist figures can become models for Muslim students. Men can become allies for women in the success of the feminist agenda (Hasyim, 2017).

Furthermore, based on the answers of male respondents, it is found that most of them are willing to become supporters of the gender equality movement, namely $63.76 \%$. Although the number is not as high as expected, this figure is good enough because of their openness to accepting the latest arguments related to Islamic teachings, especially those related to gender equality. Their desire and willingness to support the women's movement also suggests that they may also have realized the benefits of the gender equality movement for men (Flood et al., 2017). They realize that patriarchal culture is detrimental to women men (Craig, 2014; Precopio \& Ramsey, 2017). These results are under previous research, which states that men want to support and play an active role in helping the success of feminism (Bojin, 2013; Flood, 2011; Flood et al., 2017).

Several previous studies have reported various reasons why a man is willing to be involved in the gender equality movement. Men's participation in feminism is influenced by family relationships, educational experiences, and life-changing events (Kleynjan, 2019). Men who wish to engage in feminism usually focus on what drives men's relational interests (Pease, 2015). One of the reasons men support feminism is because they believe it benefits when the women around them lead safe and fair lives (Flood et al., 2017). The social construction that gives men a new perspective in seeing themselves and their relationships with women enables them to realize and then support the feminist movement (Wandi, 2015). A series of processes in men's lives also influence their mindset in playing an active role in the gender equality movement (Casey \& Smith, 2010; Hasyim, 2017). The beginning of the process is an awareness that is carried out in various ways, including being nurtured and educated by feminists. Besides, this could also be due to witnessing the oppression experienced by close people such as mothers, sisters, or female friends, or being involved in human rights movements or fighting against other forms of human oppression (Casey \& Smith, 2010; Hasyim, 2017). Thus, the feminism movement gets additional energy when men and religious moderation support, so that the gender justice 
movement becomes stronger to fight for basic human rights. Nevertheless, the gender justice movement supported by feminist men must remain in the corridor of society's Islamic values, culture, and ethics.

\section{Conclusion}

This research examines the Indonesian Muslim students towards the existence of the feminist movement, particularly the role of men in the gender equality movement. This research focuses on the relationship between the religious attitudes of students who practice moderate Islamic teachings and their attitudes towards men's involvement in supporting and participating in the feminist movement. The multiple linear regression method is applied to produce empirical evidence regarding the influence of college religious moderation on the activities of a male in supporting feminism. The results show that Muslim students practising moderate religion have a positive and statistically significant influence on the existence of male feminists who promote feminism, either actively or passively. The four independent variables that represent moderate Islamic ideology are known to have a positive and significant impact on activities carried out by men in supporting the gender equality movement. They are a sense of nationalism towards the nation and state, an attitude of tolerance, an attitude of nonviolence, and an accommodative attitude towards the culture and values of local wisdom in Indonesia. In conclusion, the four aspects of religious moderation have a linear and positive relationship with the feminist movement, including the active role of men. Thus, Muslims affiliated with moderate Islam are social capital in the success of gender equality in Indonesia. As a comparison, in-depth research based on empirical data should also be done on other Islamic ideologies, such as fundamentalist Islam or liberal Islam, and then linked to their attitudes and perceptions of the existence of male feminists or the feminist movement in general.

\section{References}

Abdurrohman, A. A. (2018). Eksistensi islam moderat dalam perspektif Islam. Rausyan Fikr: Jurnal Pemikiran Dan Pencerahan, 14(1), 29-40. https://doi.org/10.31000/rf.v14i1.671

Ahmad, M. (2020). Urban Women, Their Religion, and Response to Environmental Crisis: Empirical Evidence in Green School and Majlis Taklim Ulin Nuha. Muwazah, 12(1), 33-52. https://doi.org/https://doi.org/10.28918/muwazah.v12i1.2591

al-Qaradawi, Y. (2011). Kalimat fi al-Wasatiyyah al-Islamiyyah wa Maalimiha. Qahira: Dar al-Shuruq.

Al-Sallabi, A. M. (1999). al-Wasatiyyah fi al-Quran al-Karim. Amman: Jordan, Dar Al-Nafais \& Dar Al-Bayariq.

Alexander, A. C., \& Welzel, C. (2011). Islam and patriarchy: how robust is Muslim support for patriarchal values? International Review of Sociology, 21(2), 249-276. https://doi.org/10.1080/03906701.2011.581801

Altwaiji, M. (2011). Twenty-First Century Arab Feminism: a movement from Islamic to the Secular. International Journal in English, 2(5), 175-183.

Arivia, G. (2006). Feminisme: sebuah kata hati. Jakarta: Penerbit Buku Kompas.

Arivia, G., \& Subono, N. I. (2017). A Hundred Years of Feminism in Indonesia An Analysis of Actors. Debates and Strategies. Www. Fes-Asia. Org.

Asrini, V., \& Dhamayanti, M. (2018). Representasi laki-laki dalam perspektif men doing feminism dalam program reality show my daddy my hero. SEMIOTIKA: Jurnal Komunikasi, 11(2).

Badran, M. (2013). Feminism in Islam: Secular and religious convergences. New York: Simon and Schuster.

Baily, J. (2012). What happens when men get involved in feminism? Contemporary mixed-gender feminist activism in England. University of Sheffield.

Baily, J. (2015). Contemporary British feminism: opening the door to men? Social Movement Studies, 14(4), 443-458. https://doi.org/10.1080/14742837.2014.947251

Ben Salah, H., \& Wernli, B. (2016). Uncovering perspectives on masculinity in Swiss men's organizations using a mixed methods approach. NORMA, 11(2), 110-128. https://doi.org/10.1080/18902138.2016.1181864

Bojin, K. (2013). Feminist solidarity: no boys allowed? Views of pro-feminist men on collaboration and alliancebuilding with women's movements. Gender \& Development, 21(2), 363-379. https://doi.org/10.1080/13552074.2013.802879

Burrell, S. R., \& Flood, M. (2019). Which feminism? Dilemmas in pro-feminist men's praxis to end violence against women. Global Social Welfare, 6(4), 231-244. https://doi.org/10.1007/s40609-018-00136-x 
Casey, E., \& Smith, T. (2010). “How can I not?": Men's pathways to involvement in anti-violence against women work. Violence against Women, 16(8), 953-973. https://doi.org/10.1177/1077801210376749

Conlin, S. E., \& Heesacker, M. (2018). Feminist men?: examining men's feminist self-identification, activism and the impact of language. Journal of Gender Studies, 27(8), 928-942. https://doi.org/10.1080/09589236.2017.1371007

Craig, E. (2014). Men and Feminism: The Art of Negotiation. Vermont: Independent Study Project (ISP) Collection.

Crowe, J. (2011). Men and Feminism: Some challenges and a partial response. Social Alternatives, 30(1), 49-53.

Darajat, Z. (2017). Muhammadiyah dan NU: Penjaga Moderatisme Islam di Indonesia. Hayula: Indonesian Journal of Multidisciplinary Islamic Studies, 1(1), 81-96. https://doi.org/10.21009/hayula.001.1.05

De Wolf, P. (2015). Male feminism: men's participation in women's emancipation movements and debates. Case studies from Belgium and France (1967-1984). European Review of History: Revue Européenne d'histoire, 22(1), 77-100. https://doi.org/10.1080/13507486.2014.983427

Fadlan, F. (2012). Islam, Feminisme, dan Konsep Kesetaraan Gender dalam Al-Qur'ân. KARSA: Journal of Social and Islamic Culture, 19(2), 105-119.

Feasey, R. (2017). Masculinit (ies) and the male celebrity feminist. Men and Masculinities, 20(3), $283-293$. https://doi.org/10.1177/1097184X17718587

Flood, M. (2011). Involving men in efforts to end violence against women. Men and Masculinities, 14(3), 358-377. https://doi.org/10.1177/1097184X10363995

Flood, M., Russell, G., O'Leary, J., \& Brown, C. (2017). Men make a difference: engaging men on gender equality. Sydney: Diversity Council Australia.

Glas, S., \& Alexander, A. (2020). Explaining Support for Muslim Feminism in the Arab Middle East and North Africa. Gender \& Society, 0891243220915494. https://doi.org/10.1177/0891243220915494

Glas, S., Spierings, N., \& Scheepers, P. (2018). Re-understanding religion and support for gender equality in Arab countries. Gender \& Society, 32(5), 686-712. https://doi.org/10.1177/0891243218783670

Hanapi, M. S. (2014). The wasatiyyah (moderation) concept in Islamic epistemology: a case study of its implementation in Malaysia. International Journal of Humanities and Social Science, 4(9), 1.

Harisuddin, M. N. (2015). Pemikiran feminis muslim di Indonesia tentang fiqh perempuan. Al-Tahrir: Jurnal Pemikiran Islam, 15(2), 237. https://doi.org/10.21154/al-tahrir.v15i2.265

Hasyim, N. (2014). How far can men go? A study of the men's movement to end violence against women in Indonesia. University of Wollongong.

Hasyim, N. (2017). Laki-laki Sebagai Sekutu Gerakan Perempuan. Sawwa: Jurnal Studi Gender, 12(1), 79-90. https://doi.org/10.21580/sa.v12i1.1469

Hilmy, M. (2012). Quo-Vadis Islam Moderat Indonesia? Menimbang Kembali Modernisme Nahdlatul Ulama dan Muhammadiyah. MIQOT: Jurnal Ilmu-Ilmu Keislaman, 36(2). https://doi.org/10.30821/miqot.v36i2.127

Hooks, B. (2000). Feminism is for everybody: Passionate politics. London: Pluto Press.

Islam, T., \& Khatun, A. (2015). "Islamic Moderation" in Perspectives: A Comparison Between Oriental And Occidental Scholarships. International Journal of Nusantara Islam, 3(2), 69-78. https://doi.org/10.15575/ijni.v3i2.1414 1CITATION1 citation on Dimensions.

Jackson, L. A., Fleury, R. E., \& Lewandowski, D. A. (1996). Feminism: Definitions, support, and correlates of support among female and male college students. Sex Roles, 34(9-10), 687-693. https://doi.org/10.1007/BF01551502

Kawangung, Y. (2019). Religious moderation discourse in plurality of social harmony in Indonesia. International Journal of Social Sciences and Humanities, 3(1), 160-170. https://doi.org/10.29332/ijssh.v3n1.277

Kleynjan, P. (2019). Men in feminism: the male feminist. Western Sydney University.

Klocke, B. (2013). Roles of men with feminism and feminist theory. Retrieved 21 June 2021, from National Organization for Men Against Sexism website: https://nomas.org/roles-of-men-with-feminism-and-feministtheory/

Larasati, I., \& Astuti, P. (2019). Gerakan Aliansi Laki-Laki Baru: membongkar konstruksi maskulinitas untuk mewujudkan keadilan gender. Journal of Politic and Government Studies, 8(02), 211-220.

Lussier, D. N., \& Fish, M. S. (2016). Men, Muslims, and attitudes toward gender inequality. Politics E Religion, 9(1), 29-60. https://doi.org/10.1017/S1755048315000826

Manshur, F. M., \& Husni, H. (2020). Promoting Religious Moderation through Literary-based Learning: A QuasiExperimental Study. Dialogue, 29(6), 5849-5855.

Muhammad, K. H. H. (2019). Islam tradisional yang terus bergerak. Yogyakarta: IRCiSoD.

Parawansa, K. I. (2015). Memimpin melayani: pandangan sosial politik. Bandung: Nuansa Cendekia.

Parvanova, D. (2012). Islamic feminist activism in Indonesia: Muslim women's paths to empowerment. Austrian Studies in Social Anthropology. Sondernummer, 1(1), 11-26. 
Pease, B. (2015). Disengaging Men from Patriarchy: Rethinking the Man Question in Masculinity Studies'. In Engaging Men in Building Gender Equality (pp. 55-70). Cambridge Scholars Publishing.

Prado, A. (2012). Qur'anic Feminism: The Makers of Textual Meaning. In A Jihad for justice: honoring the work and life of Amina Wadud (p. 39). Boston: Boston University.

Prasad, A., Centeno, A., Rhodes, C., Nisar, M. A., Taylor, S., Tienari, J., \& Alakavuklar, O. N. (2021). What are men's roles and responsibilities in the feminist project for gender egalitarianism? Gender, Work $\mathcal{E}$ Organization, 28(4), 1579-1599. https://doi.org/10.1111/gwao.12573

Prasetya, O. F., \& Suprapto, D. (2020). Representasi feminis laki-laki dalam film dokumenter "surga kecil di bondowoso". Jurnal Adat Dan Budaya Indonesia, 2(2), 103-117. https://doi.org/10.23887/jabi.v2i2.28828

Precopio, R. F., \& Ramsey, L. R. (2017). Dude looks like a feminist!: Moral concerns and feminism among men. Psychology of Men E Masculinity, 18(1), 78. https://doi.org/10.1037/men0000042

Raftari, H., \& Bahrami, Z. (2011). Gender Equality according to Islam and Feminism. International Conference on Social Science and Humanity, 492-496.

Rahman, Y. (2017). Feminist Kyai, KH Husein Muhammad: The Feminist Interpretation on Gendered Verses and the Qur'ān-Based Activism. Al-Jami'ah: Journal of Islamic Studies, 55(2), $293-326$. https://doi.org/10.14421/ajis.2017.552.293-326

Rinaldo, R. (2014). Pious and critical: Muslim women activists and the question of agency. Gender E Society, 28(6), 824-846. https://doi.org/10.1177/0891243214549352

Salik, M. (2019). Conserving moderate Islam in Indonesia: An Analysis of Muwafiq's Speech on Online Media. Journal of Indonesian Islam, 13(2), 373-394. https://doi.org/10.15642/JIIS.2019.13.2.373-394

Silver, E. R., Chadwick, S. B., \& van Anders, S. M. (2019). Feminist identity in men: Masculinity, gender roles, and sexual approaches in feminist, non-feminist, and unsure men. Sex Roles, 80(5-6), 277-290. https://doi.org/10.1007/s11199-018-0932-6

Subašić, E., Hardacre, S., Elton, B., Branscombe, N. R., Ryan, M. K., \& Reynolds, K. J. (2018). "We for She": Mobilising men and women to act in solidarity for gender equality. Group Processes $\mathcal{E}$ Intergroup Relations, 21(5), 707-724. https://doi.org/10.1177/1368430218763272

Sumiyatiningsih, D. (2014). Pergeseran peran laki-laki dan perempuan dalam kajian feminis. WASKITA Jurnal Studi Agama Dan Masyarakat, Hlm, 125-138.

Sweetman, C. (2013). Introduction: Working with men on gender equality. Gender and Development, 21(1), 1-13. https://doi.org/10.1080/13552074.2013.779445

The Ministry of Religion of the Republic of Indonesia. (2019). Moderasi beragama-Religious moderation. Jakarta: Badan Litbang dan Diklat Kemenag RI.

Van der Gaag, N. (2014). Feminism and men. London: Bloomsbury Publishing.

Wandi, G. (2015). Rekonstruksi maskulinitas: menguak peran laki-laki dalam perjuangan kesetaraan gender. Kafaah: Journal of Gender Studies, 5(2), 239-255. https://doi.org/10.15548/jk.v5i2.110

Widani, A. (2017). Gender Equality and Women's Participation in Islamic Fundamentalist Groups: A Case Study of Indonesia. University of Oslo.

Wiley, S., Srinivasan, R., Finke, E., Firnhaber, J., \& Shilinsky, A. (2013). Positive Portrayals of Feminist Men Increase Men's Solidarity With Feminists and Collective Action Intentions. Psychology of Women Quarterly, 37(1), 6171. https://doi.org/10.1177/0361684312464575

Yaakub, M. B., \& Othman, K. (2016). A textual analysis for the term 'wasatiyyah (Islamic Moderation) in selected quranic verses and prophetic tradition. Journal of Education and Social Sciences, 5(1), 61-68.

(C) 2021 by the authors. Submitted for possible open access publication under the terms and conditions of the Creative Commons Attribution (CC BY SA) license (https://creativecommons.org/licenses/by-sa/3.0/). 
This page is intentionally left blank 